\title{
Diminishing Complications in Continuous Ambulatory \\ Peritoneal Dialysis Process via Six Sigma Methodology
}

\author{
Enes Murat Atasoyu \\ Department of Nephrology, Anadolu Medical Center, \\ Gebze, Turkey. Email: enes.atasoyu@ anadolusaglik.org
}

\section{Mehmet Tolga Taner}

Department of Healthcare Management, Uskudar University, Istanbul, Turkey. Email: mehmettolga.taner@uskudar.edu.tr

\section{Engin Erbas}

Institute of Health Sciences, Uskudar University, Istanbul, Turkey. Email: enginerbas78@ hotmail.com

\section{Ibrahim Sahbaz}

Vocational School of Health Sciences, Uskudar University, Istanbul, Turkey. Email: ibrahim.sahbaz@uskudar.edu.tr

\section{Gamze Kagan}

Department of Occupational Health and Safety, Uskudar University, Istanbul, Turkey. Email: gamze.kagan@uskudar.edu.tr

\section{Mehmet Kemal Kagan}

Siyami Ersek Thoracic and Cardiovascular Surgery Training and Research Hospital, Istanbul, Turkey. Email: drmehmetkagan@ hotmail.com

\section{Latif Enginyurt}

Institute of Health Sciences, Uskudar University, Istanbul, Turkey. Email: latifenginyurt@ hotmail.com

\section{Sadik Ozgur Baslangic}

Department of Business Administration, Adnan Menderes University, Aydin, Turkey. Email: ozgurbaslangic@hotmail.com

\begin{abstract}
The aim of this paper is to investigate the complications which occurred in a dialysis polyclinic during and after CAPD process and evaluate them in terms of their root causes, severity, sigma levels and hazard scores. The data are collected from 24 patients over a 12-month period. Seventeen complications are determined. Six Sigma's DMAIC, SIPOC
\end{abstract}


table, Fishbone diagram and FMEA are employed to evaluate the overall process. Vital few CTQ factors are determined to be patient's compliance to hygiene and presence of comorbid diseases such as diabetes, cardiovascular problems and obesity. Consequently, corrective actions are proposed for preventing the occurrence of the complications.

Keywords: Six Sigma; Continuous Ambulatory Peritoneal dialysis; Complications; Training JEL Classifications: I20; L15

\section{Introduction}

Continuous Ambulatory Peritoneal dialysis (CAPD) is a major therapeutic modality in the treatment of end-stage renal disease, and has been used widely across the world since its introduction in 1976 (Boeschoten, 2000). At the end of 2013, around 3,194,000 patients were treated and about 2,519,000 patients regularly underwent dialysis worldwide (Fresenius Medical Care, 2013). The same year, the number of dialysis patients rose by nearly $7 \%$ worldwide (Fresenius Medical Care, 2013). About $11 \%$ of all dialysis patients were treated by peritoneal dialysis (PD) (Fresenius Medical Care, 2013). According to the National Hemodialysis, Transplantation and Nephrology Registry Report of Turkey, 3,166 (66.37\%) patients underwent CAPD in 2012 (Ministry of Health and Turkish Society of Nephrology, 2013). Demographic trends indicate that the number of dialysis patients is expected to rise to 3,800,000 patients worldwide in 2020 (Fresenius Medical Care, 2013).

Some of the major factors driving the dialysis market growth are the growing number of patients with comorbid diseases such as diabetes, obesity, hypertension and cardiovascular problems (Fresenius Medical Care, 2013). These reasons are anticipated to increase the market growth strongly in the next decade. Although there are no acute challenges faced by the dialysis industry, the treatment procedures themselves have certain associated complication risks, such as bleeding at the exit site, tunnel infections, exit site infections, herniation (7.2\%), hyperglycemia (3.1\%), hyperlipidemia (23.4\%), inadequate dialysis $(5.6 \%)$, drainage problem (4.4\%) and obesity (8.4\%) (Sahin, 2008; Suh, 1997; Crabtree, 2006). On the other hand, peritonitis (0.43 episodes/patient/year) remains a leading complication of CAPD (Ministry of Health and Turkish Society of Nephrology, 2013) and continues to have a high rate of mortality (16\%). (Fried et al., 1996; Li et al., 2011). CAPD complications, particularly peritonitis, requires prompt diagnosis and treatment. Imaging by CT peritoneography and MR peritoneography plays a critical role in ensuring that complications are detected early and managed appropriately (Stuart et al., 2009).

The National Kidney Foundation Dialysis Outcomes Quality Initiative (NKFK/DQOI) Clinical Practice Guideline for chronic kidney disease recommend that Minimal Delivered Weekly Clearance for urea (Kt/V urea) and Weekly Creatinine Clearance are the indices that can be routinely used to measure dialysis success and adequacy. For a successful and adequate CAPD dialysis, Kt/V urea must exceed 1.7 and that of creatinine must be equal to $701 \mathrm{t} / 1.73 \mathrm{~m}^{2}$ (NKFKIDQOI, 2007). In addition, certain levels of biochemical elements in blood, absence of edema and normotension are other measurements for successful and adequate treatment (See Table 1).

This paper proposes the implementation of the Six Sigma Methodology as a quality 
management tool. In this study, a Six Sigma infrastructure was developed in a dialysis unit in order to reduce the number of complications and thus, improve the outcomes of their CAPD processes. In addition, the sigma level of each type of complication are calculated and reported.

\section{Six Sigma Methodology}

Six Sigma is a quality and process improvement method that improves the outcomes of modern healthcare processes today (Taner et al., 2007). It was initially implemented in manufacturing and service processes in e.g. automative, food, software, financial, education, textile and construction industries (Bilgen and Sen; 2012; Hung and Sung, 2011; Antony and Fergusson, 2004; Heckl et al., 2010; Jenicke et al., 2008; Taner, 2012a; Taner, 2013). In healthcare, it was implemented in the processes of stent insertion (Taner et al., 2013), ophthalmological surgeries (Ozturker et al., 2014; Sahbaz et al., 2014a; Sahbaz et al., 2014b; Sahbaz et al., 2014c; Sahbaz et al., 2014d; Sahbaz et al., 2014e; Sahbaz et al., 2014f; Taner, 2012b; Taner et al., 2014a; Taner et al., 2014b), diagnostic imaging (Taner et al., 2012), emergency room (Miller et al., 2003), intensive care (Eldridge et al., 2006), paramedic backup (Taner and Sezen, 2009), laboratory (Nevalainen et al., 2000), radiology (Cherry and Seshadri, 2000), pharmacy (Arafeh et al., 2014), hemodialysis (Ekinci et al., 2015) and surgical site infections (Pexton and Young, 2004).

A “Six Sigma process" produces only 3.4 defective products per 1,000,000 opportunities (DPMO) (Buck, 2001). To minimize and/or eliminate defects, Six Sigma makes use of a structured methodology called DMAIC (Define-Measure-Analyze-Improve-Control) to find the root causes behind them. (Park and Antony, 2008). DMAIC analyses and modifies processes by defining problems, identifying process objective(s), eliminating root causes of defects, errors or complications; and consequently, minimizing process variability (Taner et al., 2007).

Six Sigma uses statistical assumptions of the normal distribution and calculates the DPMO from Equation (1) (Taner et al., 2012):

$$
\mathrm{DPMO}=1,000,000 \times(\mathrm{TNP} / \mathrm{TNPC})
$$

where TNP is the total number of CAPD patients with the complication and TNPC is the total number of CAPD patients. Following this, the sigma level is calculated directly from DPMO by simple arithmetic. The higher level of sigma indicates a lower rate of complications and a more efficient CAPD process (Taner et al., 2013).

\section{a. Define Phase}

When the dialysis unit realized that they had been suffering from high complication occurrence rates of exit site infection and peritonitis, they decided to focus attention on prevention and treatment of these complications. Experiencing high rates of peritonitis had resulted in the loss of patients since patients had to discontinue CAPD and switch to hemodialysis. This was the rationale that they decided to implement a quality management system in the polyclinic. They found that best way to eliminate and/or prevent these complications was to initiate Six Sigma's DMAIC tool. First, a Six Sigma team was assembled comprising of a nephrologist and PD nurse, and who were trained in the 
methodology. Then, they generated a SIPOC (Supplier, Input, Process, Output and Customer) Table for the CAPD process (Table 1). Then, they determined the metrics to measure the existing level of process. The following four metrics were chosen for the Six Sigma study:

1. Total number of CAPD processes performed in the dialysis unit,

2. Total count of complications occurred by type,

3. Total count of CAPD patients,

4. Total count of CAPD patients who experienced each type of complication.

Table 1. SIPOC Table for CAPD Process

\begin{tabular}{|c|c|c|c|c|}
\hline SUPPLIERS & INPUTS & PROCESS & OUTPUTS & CUSTOMER \\
\hline Nephrologist & Patient & \multirow{9}{*}{$\begin{array}{l}\text { CAPD } \\
\text { process }\end{array}$} & $\mathrm{Kt} / \mathrm{V}$ urea $>1.7$ & Patient \\
\hline \multirow[t]{8}{*}{ PD Nurse } & $\begin{array}{l}\text { Tenckhoff } \\
\text { Catheter }\end{array}$ & & $\begin{array}{l}\text { Urine output } \\
>100 \mathrm{ml} / \text { day }\end{array}$ & \\
\hline & Connection set & & $\begin{array}{c}\text { Hemoglobin } \\
\text { level }>11 \mathrm{mg} / \mathrm{dl}\end{array}$ & \\
\hline & Dialysate & & $\begin{array}{c}\text { Serum Albumin } \\
\text { level }>4 \mathrm{gr} / \mathrm{dl}\end{array}$ & \\
\hline & Mini cap & & $\begin{array}{c}\text { Serum Calcium level } \\
(9.5-10.5 \mathrm{mg} / \mathrm{dl})\end{array}$ & \\
\hline & $\begin{array}{c}\text { Soap/Disinfectant } \\
\text { gel }\end{array}$ & & $\begin{array}{c}\text { Serum } \\
\text { Bicarbonate }>22 \mathrm{mEq} / 1\end{array}$ & \\
\hline & & & $\begin{array}{c}\text { Serum Phosphorous } \\
<4.5 \mathrm{mg} / \mathrm{dl}\end{array}$ & \\
\hline & & & Normotension & \\
\hline & & & No edema & \\
\hline
\end{tabular}

The team defined a "complication" as any undesired outcome that might inhibit the patient from being cured and stable (Taner, 2012). They noted that some complications were exacerbated by comorbid conditions (Table 2). Then, they determined by brainstorming the CTQ factors, i.e. the factors that may have an influence on the occurrence of complications (Figure 1).

Table 2. Cause of Complication per Comorbid Disease

\begin{tabular}{|c|c|}
\hline Comorbid Disease & Complication \\
\hline Diabetes & Hyperglycemia \\
\hline Cardiovascular problem & Edema \\
\hline Obesity & Pericatheter leakage \\
\hline
\end{tabular}

\section{a. Measure Phase}

The team followed up twenty-four patients for 12-months, identified seventeen types of complications and classified them as how soon they occur, i.e. acute and/or sub-acute and/or chronic (Table 3). 
Figure 1. Fishbone Diagram

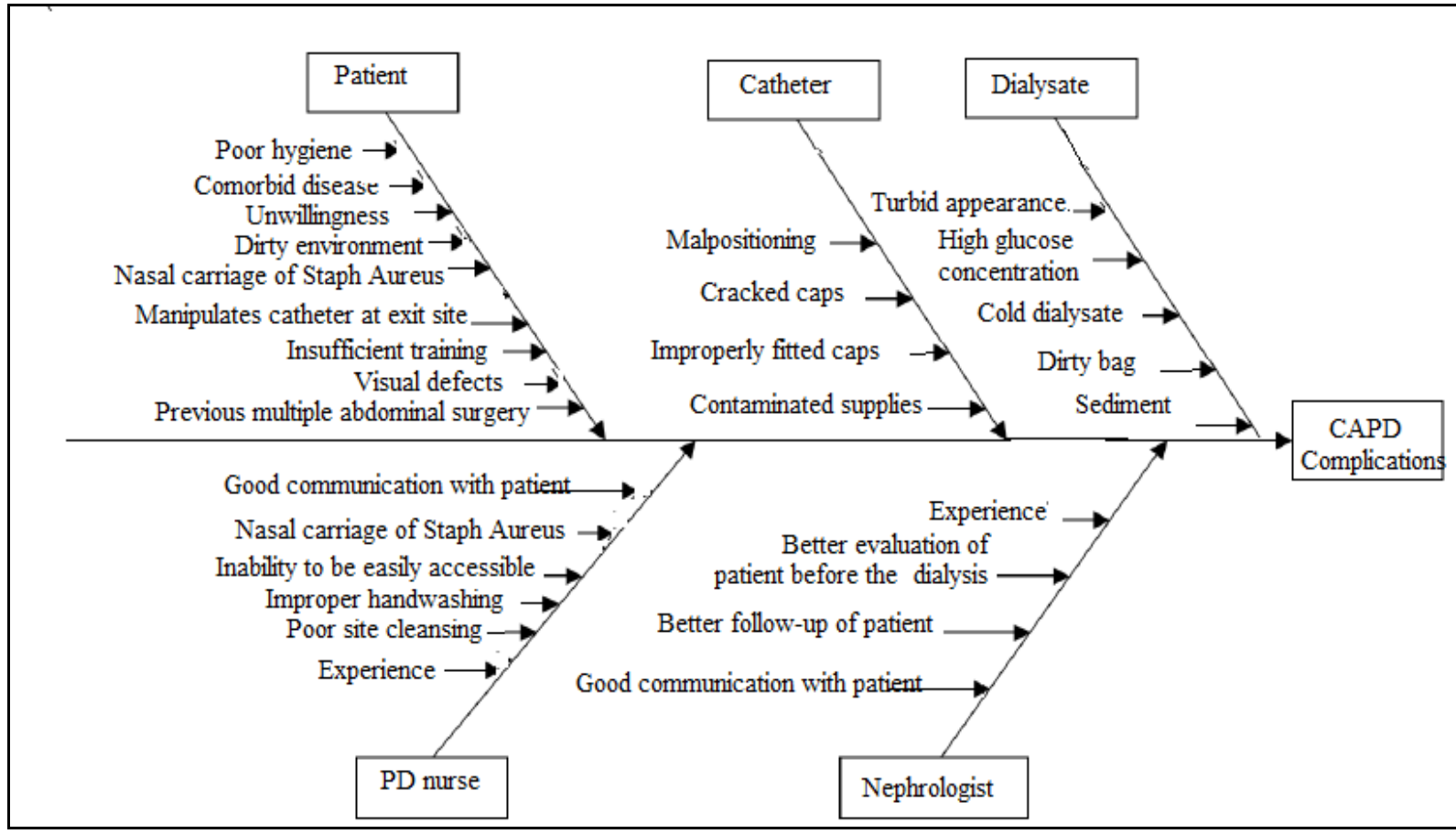

Table 3. Complications

\begin{tabular}{|c|c|c|c|c|}
\hline & Complication & Acute & Sub-Acute & Chronic \\
\hline Type I & Peritonitis & + & - & - \\
\hline Type II & Catheter malposition & + & + & - \\
\hline Type III & $\begin{array}{c}\text { Catheter cuff } \\
\text { extrusion }\end{array}$ & + & - & + \\
\hline Type IV & Malnutrition & - & - & + \\
\hline Type V & Obesity & - & - & + \\
\hline Type VI & Bleeding exit site & + & - & - \\
\hline Type VII & Intestinal perforation & + & - & - \\
\hline Type VIII & Ultrafiltration failure & + & - & + \\
\hline Type IX & Outflow failure & + & - & - \\
\hline Type X & Peritoneal sclerosis & - & - & + \\
\hline Type XI & Hemoperitoneum & + & - & + \\
\hline Type XII & Abdominal wall & - & - & + \\
\hline Type XIII & Tunnel infections & + & - & - \\
\hline Type XIV & Exit site infections & + & + & + \\
\hline Type XV & Pericatheter leakage & + & - & + \\
\hline Type XVI & Hyperglycemia & + & - & + \\
\hline Type XVII & Hypokalemia & + & + & - \\
\hline
\end{tabular}


Sources (Table 4) and root-causes (Table 5) of the complications were tabulated. According to the brainstorming, the sources of complications were determined to be resulting from the nephrologist $(\mathrm{N})$, PD Nurse (PDN), patient (P), dialysate (D) and catheter (C). Then, the team analyzed the occurrence frequency of each complication (Table 6) and related them with these root-causes. The analysis revealed that peritonitis, catheter malpositioning and exit site infections were the three most frequently occurring complications in the CAPD processes. Then, the CTQs are classified as "vital few factors" and "trivial many factors" according to how frequent they caused the complications. The "vital few" factors, i.e. the factors that had the most impact on the success of CAPD procedure were determined to be patient's compliance to treatment (PC) and presence of a comorbid disease (CD). The other factors, i.e. experience of nephrologist (EN), PD nurse's attention and experience (NAE), type of dialysate solution (TDS) and type of catheter (TC) were found to be the "trivial many" factors.

Table 4. Sources of Complications

\begin{tabular}{|c|c|c|c|c|c|c|}
\hline & & N & PDN & P & D & C \\
\hline Type I & Peritonitis & - & + & + & - & - \\
\hline Type II & Catheter malposition & + & - & - & - & + \\
\hline Type III & Catheter cuff extrusion & - & - & - & - & - \\
\hline Type IV & Malnutrition & + & + & + & + & - \\
\hline Type V & Obesity & - & - & + & + & - \\
\hline Type VI & Bleeding exit site & + & - & + & - & - \\
\hline Type VII & Intestinal perforation & + & - & - & - & - \\
\hline Type VIII & Ultrafiltration failure & - & - & + & - & - \\
\hline Type IX & Outflow failure & - & + & + & - & + \\
\hline Type X & Peritoneal sclerosis & - & - & + & + & - \\
\hline Type XI & Hemoperitoneum & - & - & + & - & - \\
\hline Type XII & Abdominal wall & - & + & + & + & - \\
\hline Type XIII & Tunnel infections & - & + & + & - & + \\
\hline Type XIV & Exit site infections & - & + & + & - & - \\
\hline Type XV & Pericatheter leakage & + & - & - & - & - \\
\hline Type XVI & Hyperglycemia & - & - & + & + & - \\
\hline Type & Hypokalemia & + & - & - & + & - \\
\hline XVII & & & + & & & + \\
\hline
\end{tabular}

The surgical team calculated the DPMO and sigma levels for each complication type (Table 6). The lowest sigma level was obtained for peritonitis. Intestinal perforation and abdominal wall herniation were found to have the highest sigma level. Having sigma levels lower than 4.00; all complications needed to be reduced. The sigma level obtained for the initial month after the initiation of Six Sigma, calculated as the arithmetic average of seventeen complications, was found to be 2.5076 . 
Table 5. Root-causes of Complications

\begin{tabular}{|c|c|c|c|c|c|c|c|}
\hline & & EN & NAE & CT & TDS & CD & TC \\
\hline Type I & Peritonitis & - & + & + & - & + & - \\
\hline Type II & Catheter malposition & + & - & - & - & + & + \\
\hline Type III & Catheter cuff extrusion & + & + & + & - & - & - \\
\hline Type IV & Malnutrition & + & - & + & + & + & - \\
\hline Type V & Obesity & - & - & + & + & + & - \\
\hline Type VI & Bleeding exit site & + & - & + & - & + & - \\
\hline Type VII & Intestinal perforation & + & - & - & - & - & - \\
\hline Type VIII & Ultrafiltration failure & - & - & - & + & + & - \\
\hline Type IX & Outflow failure & - & + & + & - & - & + \\
\hline Type X & Peritoneal sclerosis & - & - & + & + & - & - \\
\hline Type XI & Hemoperitoneum & - & - & + & - & + & - \\
\hline Type XII & Abdominal wall herniation & - & + & + & - & + & - \\
\hline Type XIII & Tunnel infections & - & + & + & - & + & + \\
\hline Type XIV & Exit site infections & - & + & + & - & + & - \\
\hline Type XV & Pericatheter leakage & + & - & - & - & + & - \\
\hline Type XVI & Hyperglycemia & - & - & - & + & + & - \\
\hline $\begin{array}{l}\text { Type } \\
\text { XVII }\end{array}$ & Hypokalemia & + & - & + & + & - & - \\
\hline
\end{tabular}

The surgical team calculated the DPMO and sigma levels for each complication type (Table 6). The lowest sigma level was obtained for peritonitis. Intestinal perforation and abdominal wall herniation were found to have the highest sigma level. Having sigma levels lower than 4.00; all complications needed to be reduced. The sigma level obtained for the initial month after the initiation of Six Sigma, calculated as the arithmetic average of seventeen complications, was found to be 2.5076 .

\section{c. Analyze Phase}

Risk assessment of CAPD processes was achieved by Failure, Mode and Effect Analysis (FMEA) (Ookalkar et al., 2009). Utilization of the FMEA involved break down the process into individual steps: potential failure modes (i.e. complications), severity score, probability score, hazard score, criticality and detection, so that the Six Sigma team could look at key drivers in the process based on the past experience (Taner et al., 2012). Complication trends and their consequences had been monitored and recorded. The Six Sigma team classified the complications according to how serious their consequences were (i.e. severity score), how frequently they occurred (i.e. probability score) and how easily they could be detected. They also determined the severity of each complication by assigning scores for them from 1 to 4 (Table 7). For each complication type, the hazard score was calculated by multiplying the severity score with the probability score. Consequently, an FMEA was tabulated (Table 8). 
Table 6. DPMO and Sigma Levels per Complication Type (January 2014)

\begin{tabular}{|c|c|c|c|c|c|}
\hline & Complication & $\begin{array}{c}\text { Number of } \\
\text { Patient } \\
\text { w/complication }\end{array}$ & $\begin{array}{c}\text { Episodes per } \\
\text { Patient (\%) }\end{array}$ & DPMO & Sigma Level \\
\hline Type I & Peritonitis & 14 & 58.33 & 583,333 & 1.29 \\
\hline Type II & $\begin{array}{c}\text { Catheter } \\
\text { malpositioning }\end{array}$ & 6 & 25.00 & 250,000 & 2.17 \\
\hline Type III & $\begin{array}{c}\text { Catheter cuff } \\
\text { extrusion }\end{array}$ & 3 & 12.50 & 125,000 & 2.65 \\
\hline Type IV & Malnutrition & 4 & 16.66 & 166,667 & 2.47 \\
\hline Type V & Obesity & 5 & 20.83 & 208,333 & 2.31 \\
\hline Type VI & Bleeding exit site & 2 & 8.33 & 83,333 & 2.88 \\
\hline Type VII & Intestinal perforation & 1 & 4.16 & 41,667 & 3.23 \\
\hline Type VIII & Ultrafiltration failure & 5 & 20.83 & 208,333 & 2.31 \\
\hline Type IX & Outflow failure & 3 & 12.50 & 125,000 & 2.65 \\
\hline Type X & Peritoneal sclerosis & 2 & 8.33 & 83,333 & 2.88 \\
\hline Type XI & Hemoperitoneum & 3 & 12.50 & 125,000 & 2.65 \\
\hline Type XII & Abdominal wall & 1 & 4.16 & 41,667 & 3.23 \\
\hline Type XIII & Tunnel infections & 3 & 12.50 & 125,000 & 2.65 \\
\hline Type XIV & Exit site infections & 6 & 25.00 & 250,000 & 2.17 \\
\hline Type XV & Pericatheter leakage & 4 & 16.66 & 166,667 & 2.47 \\
\hline Type XVI & Hyperglycemia & 5 & 20.83 & 208,333 & 2.31 \\
\hline Type XVII & Hypokalemia & 5 & 20.83 & 208,333 & 2.31 \\
\hline
\end{tabular}

Table 7. Severity Scores

\begin{tabular}{|c|c|c|c|c|}
\hline Severity Score & $\mathbf{4}$ & $\mathbf{3}$ & $\mathbf{2}$ & $\mathbf{1}$ \\
\hline $\begin{array}{c}\text { Severity of } \\
\text { Complication }\end{array}$ & Death & Permanent harm & Temporary harm & No harm \\
\hline
\end{tabular}

\section{d. Improve Phase}

The dialysis unit started to undertake a regular audit of peritonitis and infection rates. To reduce the infections, the staff in the dialysis unit were trained in infection prevention and control practices including proper hand hygiene technique.

Patient education was a fundamental and essential component of CAPD. In the Six Sigma team, PD nurses were in the most critical position by being responsible for treating the patients; educating them and motivating the unwilling ones. The licensed PD nurses provided knowledge, skills, and abilities that allowed patients to take ownership of their care to improve their own outcomes. The patients were trained on hygiene rules, exit site care, symptoms associated with disease, complex diet, and medication plans, as well as competencies required to self-manage CAPD. Patients were taught the signs and symptoms of exit infections and were encouraged to notify the nephrologists and PD nurses. 
Table 8. FMEA Table (January 2014)

\begin{tabular}{|c|c|c|c|c|c|}
\hline \multirow{2}{*}{$\begin{array}{c}\text { Complication } \\
\text { Type }\end{array}$} & $\begin{array}{c}\text { Severity } \\
\text { Score }\end{array}$ & $\begin{array}{c}\text { Probability } \\
\text { Score }\end{array}$ & $\begin{array}{c}\text { Hazard } \\
\text { Score }\end{array}$ & Critical? & Detectable? \\
\hline Type I & 4 & 0.5833 & 2.3332 & Yes & No \\
\hline Type II & 2 & 0.2500 & 0.5000 & No & No \\
\hline Type III & 3 & 0.1250 & 0.3750 & Yes & Yes \\
\hline Type IV & 4 & 0.1666 & 0.6664 & Yes & Yes \\
\hline Type V & 3 & 0.2083 & 0.6249 & Yes & Yes \\
\hline Type VI & 2 & 0.0800 & 0.1600 & No & No \\
\hline Type VII & 4 & 0.0400 & 0.1600 & Yes & No \\
\hline Type VIII & 4 & 0.2000 & 0.8000 & Yes & Yes \\
\hline Type IX & 2 & 0.1250 & 0.2500 & No & No \\
\hline Type X & 4 & 0.0800 & 0.3200 & Yes & No \\
\hline Type XI & 2 & 0.0125 & 0.0250 & No & No \\
\hline Type XII & 3 & 0.0416 & 0.1248 & Yes & No \\
\hline Type XIII & 4 & 0.1250 & 0.5000 & Yes & Yes \\
\hline Type XIV & 2 & 0.2500 & 0.5000 & No & Yes \\
\hline Type XV & 2 & 0.1666 & 0.3332 & No & Yes \\
\hline Type XVI & 3 & 0.2083 & 0.6249 & Yes & Yes \\
\hline Type XVII & 4 & 0.2083 & 0.8332 & Yes & Yes \\
\hline
\end{tabular}

The PD nurses were also in a position to assure that patients' medications and treatment were administered correctly and monitor the CAPD process on a daily basis. To achieve these vital tasks, the nurses were first trained on the principles of CAPD (both anatomy and physiology) and the nursing care of CAPD patients. Second, they learned how to perform all CAPD procedures properly and safely. Third, they did health assessment for comorbid diseases and explain the dietary information, blood test results to the patients, and initial management of co-morbid diseases such as diabetes mellitus, hypertension, hypotension, arrhythmia, infection, and cardiovascular disease. Next, they learned how to detect abnormalities and gave a first aid to prevent the CAPD complications. Consequently, they were able to manage quality control in the unit by also discussing the problems with the multidisciplinary Six Sigma team to elucidate the best solution for the patients and their families. The Six Sigma team determined that the skill and technique of a nephrologist in placing and removing catheters were crucial in CAPD. Thus, nephrologists were trained to improve their skills and techniques. 
Table 9. Preventative Measure(s) per Complication

\begin{tabular}{|c|c|c|}
\hline $\begin{array}{l}\text { Complication } \\
\text { Type }\end{array}$ & Complication Name & Preventative Measure(s) \\
\hline Type I & Peritonitis & $\begin{array}{l}\text {-Educate the patient on CAPD. } \\
\text {-Train the patient for full compliance with } \\
\text { hygiene rules. }\end{array}$ \\
\hline Type II & Catheter malposition & $\begin{array}{l}\text {-Train the nephrologist. } \\
\text {-Select the optimal catheter insertion } \\
\text { technique. }\end{array}$ \\
\hline Type III & Catheter cuff extrusion & $\begin{array}{l}\text {-Educate patient the on CAPD. } \\
\text {-Do not pull the catheter. } \\
\text {-Create a sufficient length of catheter's } \\
\text { tunnel. }\end{array}$ \\
\hline Type IV & Malnutrition & -Optimal dietary protein intake. \\
\hline Type V & Obesity & $\begin{array}{l}\text {-Select the glucose-sparing solutions. } \\
\text {-Restrict calorie intake. } \\
\text {-Counsel the patient on healthy life style. }\end{array}$ \\
\hline Type VI & Bleeding exit site & $\begin{array}{l}\text {-Educate the patient on CAPD. } \\
\text {-Protect the catheter from mechanical } \\
\text { trauma. } \\
\text {-Before the catheter insertion, cessate the } \\
\text { antiaggregant, anticoagulant medicine. }\end{array}$ \\
\hline Type VII & Intestinal perforation & $\begin{array}{l}\text {-Train the nephrologist. } \\
\text {-Select the optimal catheter insertion } \\
\text { technique. }\end{array}$ \\
\hline Type VIII & Ultrafiltration failure & $\begin{array}{l}\text {-Appropriately select the continuous } \\
\text { peritoneal dialysis type. }\end{array}$ \\
\hline Type IX & Outflow failure & $\begin{array}{l}\text {-Educate the patient on CAPD. } \\
\text {-Use appropriate catheter placement } \\
\text { technique. } \\
\text {-Use daily intracatheter heparin. }\end{array}$ \\
\hline Type X & Peritoneal sclerosis & $\begin{array}{l}\text {-Make effort to prevent the development } \\
\text { of peritonitis. } \\
\text {-Adjust the CAPD regimen for maximum } \\
\text { biocompatibility. }\end{array}$ \\
\hline Type XI & Hemoperitoneum & $\begin{array}{l}\text {-Educate the patient on CAPD. } \\
\text {-Protect the catheter and abdominal wall } \\
\text { from mechanical trauma. } \\
\text {-Use intraperitoneal heparin to avoid } \\
\text { clotting catheter flushing. }\end{array}$ \\
\hline Type XII & $\begin{array}{l}\text { Abdominal wall } \\
\text { herniation }\end{array}$ & $\begin{array}{l}\text {-Pay attention to patients with a history } \\
\text { intrabdominal multiple surgeries or } \\
\text { pregnancies. }\end{array}$ \\
\hline
\end{tabular}




\begin{tabular}{|c|c|c|}
\hline Type XIII & Tunnel infections & $\begin{array}{l}\text {-Educate the patient on CAPD. } \\
\text {-Train the patient for full compliance with } \\
\text { hygiene rules. }\end{array}$ \\
\hline Type XIV & Exit site infections & $\begin{array}{l}\text {-Educate the patient on CAPD. } \\
\text {-Train the patient for full compliance with } \\
\text { hygiene rules. }\end{array}$ \\
\hline Type XV & Pericatheter leakage & $\begin{array}{l}\text {-Educate the patient on CAPD. } \\
\text {-Pay attention to patients with morbid } \\
\text { obesity and initially use low-volume } \\
\text { dialysate. }\end{array}$ \\
\hline Type XVI & Hyperglycemia & -Select the glucose-sparing solutions. \\
\hline Type XVII & Hypokalemia & $\begin{array}{l}\text {-Administer oral potassium chloride } \\
\text { supplementation. }\end{array}$ \\
\hline
\end{tabular}

Consequently, the Six Sigma team decided that the risks associated with the complications could be minimized by taking the necessary preventative measures to control the CAPD process. This was achieved by a careful preoperative examination and evaluation to detect the presence of a comorbid disease in patient, attention to the catheter placing and removal technique, and rigorous care during the intra and postoperative period.

The Six Sigma team developed preventative measures for each type of complication in order to bring the overall process under control (Table 9).

After the improvements in the unit, the occurrence rates of complications were significantly reduced (Table 10). Complications such as bleeding exit site, intestinal perforation, outflow failure, peritoneal sclerosis and abdominal wall herniation were completely eliminated in the process. On target improvement, i.e. maximum sigma level $(+\infty)$ was achieved for these complications. To eliminate the rest of the complications, the process will be continuously improved. Table 11 summarizes the improvement rates (\%) in the unit. It is observed that improvements are achieved for all types of complications, however in different levels.

\section{e. Control Phase}

The patients' understanding of the CAPD process and support systems were continuously checked, after the education by the PD nurse on how to care for the catheter and to address any gaps in understanding that might have existed. The patients received ongoing monitoring to ensure adequate dialysis, and be regularly assessed for complications. Special attention was given to monitoring and management of peritonitis, exit site infections and malpositioned catheters. Complication occurrence rates were continuously monitored and reported. Finally, an improved process was institutionalized. 
Table 10. DPMO and Sigma Levels per Complication Type (December 2014)

\begin{tabular}{|c|c|c|c|c|c|}
\hline & Complication & $\begin{array}{c}\text { Number of } \\
\text { Patient } \\
\text { w/complication }\end{array}$ & $\begin{array}{c}\text { Episodes per } \\
\text { Patient (\%) }\end{array}$ & DPMO & Sigma Level \\
\hline Type I & Peritonitis & 2 & 8.33 & 83,333 & 2.88 \\
\hline Type II & $\begin{array}{c}\text { Catheter } \\
\text { malpositioning }\end{array}$ & 1 & 4.17 & 41,666 & 3.23 \\
\hline Type III & $\begin{array}{c}\text { Catheter cuff } \\
\text { extrusion }\end{array}$ & 1 & 4.17 & 41,666 & 3.23 \\
\hline Type IV & Malnutrition & 1 & 4.17 & 41,666 & 3.23 \\
\hline Type V & Obesity & 2 & 8.33 & 83,333 & 2.88 \\
\hline Type VI & Bleeding exit site & 0 & 0 & 0 & On Target \\
\hline Type VII & Intestinal perforation & 0 & 0 & 0 & On Target \\
\hline Type VIII & Ultrafiltration failure & 1 & 4.17 & 41,666 & 3.23 \\
\hline Type IX & Outflow failure & 0 & 0 & 0 & On Target \\
\hline Type X & Peritoneal sclerosis & 0 & 0 & 0 & On Target \\
\hline Type XI & Hemoperitoneum & 1 & 4.17 & 41,666 & 3.23 \\
\hline Type XII & Abdominal wall & 0 & 0 & 0 & On Target \\
\hline Type XIII & Tunnel infections & 1 & 4.17 & 41,666 & 3.23 \\
\hline Type XIV & Exit site infections & 1 & 4.17 & 41,666 & 3.23 \\
\hline Type XV & Pericatheter leakage & 1 & 4.17 & 41,666 & 3.23 \\
\hline Type XVI & Hyperglycemia & 2 & 8.33 & 83,333 & 2.88 \\
\hline Type XVII & Hypokalemia & 2 & 8.33 & 83,333 & 2.88 \\
\hline
\end{tabular}

\section{Conclusions}

In this study, adequacy of dialysis, reduction of complications, prevention of infections and malnutrition, documentation of patient education and patient satisfaction were the Six Sigma projects handled by the Six Sigma team. These projects facilitated the optimal long-term management of the complications in the dialysis unit.

The authors identified and reported seventeen types of complications encountered during and after CAPD processes. FMEA revealed that peritonitis yielded the highest hazard score. Likewise, hemoperitoneum was found to be the least hazardous complication.

The highest sigma level was found to be associated with intestinal perforation and abdominal wall herniation, whereas peritonisis yielded the lowest sigma level. Peritonitis, catheter malpositioning and exit site infections were the three most frequently occurring complications in the dialysis unit. Known as the most risky complication, peritonitis received the utmost care and attention.

Reduction and/or complete elimination of complications by training the PD nurses and educating the patients on CAPD and hygiene, resulted in diminished occurrence rates of complications as well as decreased costs and psychological burden on the patients and families. 
Limitation of the study was the low number of patients. This has resulted in seemingly low sigma levels for some complications although implementing Six Sigma has successfully reduced their occurrence rates as well. Future study will concentrate on the implementation of Six Sigma methodology to minimize the complications in home-based dialysis.

Table 11. Improvement Rate per Complication Type (\%)

\begin{tabular}{|c|c|c|c|c|}
\hline & Complication & $\begin{array}{c}\text { Episodes per } \\
\text { Patient (\%) } \\
\text { (January } \\
\mathbf{2 0 1 4})\end{array}$ & $\begin{array}{c}\text { Episodes per } \\
\text { Patient (\%) } \\
\text { (December } \\
\mathbf{2 0 1 4}\end{array}$ & $\begin{array}{c}\text { Improvement } \\
\text { Rate } \\
(\boldsymbol{\%})\end{array}$ \\
\hline Type I & Peritonitis & 58.33 & 4.17 & 92.85 \\
\hline Type II & $\begin{array}{c}\text { Catheter } \\
\text { malpositioning }\end{array}$ & 25.00 & 4.17 & 83.32 \\
\hline Type III & $\begin{array}{c}\text { Catheter cuff } \\
\text { extrusion }\end{array}$ & 12.50 & 4.17 & 66.64 \\
\hline Type IV & Malnutrition & 16.66 & 4.17 & 74.97 \\
\hline Type V & Obesity & 20.83 & 8.33 & 60.01 \\
\hline Type VI & Bleeding exit site & 8.00 & 0 & 100.00 \\
\hline Type VII & Intestinal perforation & 4.16 & 0 & 100.00 \\
\hline Type VIII & Ultrafiltration failure & 20.83 & 4.17 & 79.98 \\
\hline Type IX & Outflow failure & 12.50 & 0 & 100.00 \\
\hline Type X & Peritoneal sclerosis & 8.00 & 0 & 100.00 \\
\hline Type XI & Hemoperitoneum & 12.50 & 4.17 & 66.64 \\
\hline Type XII & Abdominal wall & 4.16 & 0 & 100.00 \\
\hline Type XIII & Tunnel infections & 12.50 & 4.17 & 66.64 \\
\hline Type XIV & Exit site infections & 25.00 & 4.17 & 83.32 \\
\hline Type XV & Pericatheter leakage & 16.66 & 4.17 & 74.97 \\
\hline Type XVI & Hyperglycemia & 20.83 & 8.33 & 60.01 \\
\hline Type XVII & Hypokalemia & 20.83 & 8.33 & 60.01 \\
\hline
\end{tabular}

\section{References}

Antony, J., Fergusson, C. (2004), Six Sigma in the Software Industry: Results from a Pilot Study, Managerial Auditing Journal, 19(8), 1025-1032.

Arafeh, M., Barghash, M.A., Sallam, E., AlSamhouri, A. (2014), Six Sigma Applied to Reduce Patients' Waiting Time in a Cancer Pharmacy, International Journal of Six Sigma and Competitive Advantage, 8(2), 105-124.

Bersenas, A.M.E. (2011), A Clinical Review of Peritoneal Dialysis, Journal of Veterinary Emergency and Critical Care, 21, 605-617

Bilgen, B., Sen, M. (2012), Project Selection Through Fuzzy Analytic Hierarchy Process and a Case Study on Six Sigma Implementation in an Automotive Industry, Production Planning and Control, 23(1), 2-25. 
Boeschoten, E.W. (2000), Continuous Ambulatory Peritoneal Dialysis, in Textbook of Peritoneal Dialysis, Gokal R. , Khanna R., Krediet, R. and Nolph K. (eds.), Kluwer Academic Publications, 2nd edition, The Netherlands.

Buck, C. (2001), Application of Six Sigma to Reduce Medical Errors, Annual Quality Congress Proceedings, April 11-15, Charlotte, 739-742.

Cherry, J., Seshadri, S. (2000), Six Sigma: Using Statistics to Reduce Process Variability and Costs in Radiology, Radiology Management, 22(6), 42-49.

Crabtree, J.H. (2006), Rescue and Salvage Procedures for Mechanical and Infectious Complications of Peritoneal Dialysis, International Journal of Artificial Organs, 29(1), 67-84.

Ekinci, C.G., Taner, M.T., Erbas, E. (2015), Integration of Six Sigma Methodology to Reduce Complications in a Private Hemodialysis Center, International Review of Management and Marketing, 5(1), 36-43.

Eldridge, N.E., Woods, S.S., Bonello, R.S., Clutter, K., Ellingson, L., Harris, M.A., Livingston, B.K., Bagian, J.P., Danko, L.H., Dunn, E.J., Parlier, R.L., Pederson, C., Reichling, K.J., Roselle, G.A., Wright, S.M. (2006), Using the Six Sigma Process to Implement the Centers for Disease Control and Prevention Guideline for Hand Hygiene in 4 Intensive Care Units, Journal of General Internal Medicine, 21(2), 35-42.

Fresenius Medical Care (2013), Annual Report, Germany. Accessed from: www.fmc-ag.com/files/FMC_Annual_Report_2013_en.pdf

Fried, L.F., Bernardini, J., Johnston, J.R., Piraino, B. (1996), Peritonitis Influences Mortality in Peritoneal Dialysis Patients, Journal of American Society of Nephrology, 7(10), 2176-2182.

Heckl, D., Moormann, J., Rosemann, M. (2010), Uptake and Success Factors of Six Sigma in the Financial Services Industry, Business Process Management Journal, 16(3), 436-472.

Hung, H.C., Sung, M.H. (2011), Applying Six Sigma to Manufacturing Processes in the Food Industry to Reduce Quality Cost, Scientific Research and Essays, 6(3), 580-591.

Jenicke, L.O., Kumar, A., Holmes, M.C. (2008), A framework for Applying Six Sigma Improvement Methodology in an Academic Environment, The TQM Journal, 20(5), 453-462.

Li, P.K.T., Szeto, C.C., Piraino, B., Bernardini, J., Figueiredo, A.E., Gupta, A., Johnson, D.W., Kuijper, E.J., Lye, W.C., Salzer, W., Schaefer, F., Struijk, D.G. (2010), Peritoneal Dialysis-Related Infections Recommendations: 2010 Update, Peritoneal Dialysis International, 30(4), 393-423.

Mandal, A.K., Prakash, J. (2014), Textbook of Nephrology, Jaypee Brothers Medical Publishers, 3rd Edition, India.

Miller, M.J., Ferrin, D.M., Szymanski, J.M. (2003), Simulating Six Sigma Improvement Ideas for Hospital Emergency Department, Proceedings Of The IEEE Winter Simulation Conference, New Orleans, December 7-10, 1926-1929.

Ministry of Health and Turkish Society of Nephrology (2013), National Hemodialysis, Transplantation and Nephrology Registry Report of Turkey, Suleymanlar G., Altiparmak M.R. Seyahi N. and Trabulus S. (eds.), Turkish Society of Nephrology 
Publications, Ankara, Turkey. (Accessed from http://www.tsn.org.tr)

National Institutes of Health, National Institute of Diabetes and Digestive and Kidney Diseases (2007), 2007 Annual Data Report: Atlas of End-Stage Renal Disease in the United States, United States Renal Data System, Bethesda, USA.

NKFK - National Kidney Foundation Kidney (2006), NKFK/DOQI Clinical Practice Guidelines: Anaemia of Chronic Kidney Disease: II. Anemia Work-up: Guidelines 1, 2, 3. (Accessed from http://patients.uptodate.com)

Nevalainen, D., Berte, L., Kraft, C., Leigh, E., Picaso, L., Morgan, T. (2000), Evaluating Laboratory Performance on Quality Indicators with the Six Sigma Scale, Archives of Pathology and Laboratory Medicine, 124, April, 516-519.

Oztürker, C., Sahbaz, I., Oztürker, Z.K., Taner, M.T., Bayraktar, S. ve Kagan, G. (2014), "Development of a Six Sigma Infastructure for Trabulectomy Process", American Journal of Operations Research 4(4), 246-254.

Park, S.H., Antony, J. (2008), Robust Design for Quality Engineering and Six Sigma, World Scientific Publishing, New Jersey, USA.

Pexton, C., Young, D. (2004), Reducing Surgical Site Infections through Six Sigma and Change Management, Patient Safety and Quality Healthcare, July/September, 1-8.

Sahbaz, I., Taner, M.T., Eliacik, M., Kagan, G., Erbas, E. (2014a), Adoption of Six Sigma's DMAIC to Reduce Complications in IntraLase Surgeries, International Journal of Statistics in Medical Research, 3(2), 126-133.

Sahbaz, I., Taner, M.T., Eliacik, M., Kagan, G., Erbas, E., Enginyurt, H. (2014b), Deployment of Six Sigma Methodology to Reduce Complications in Intravitreal Injections, International Review of Management and Marketing, 4(2), 160-166.

Sahbaz, I., Taner, M.T., Kagan, G., Sanisoglu, H., Durmus, E., Tunca, M., Erbas, E., Kagan, S.B., Kagan, M.K., Enginyurt, H. (2014c), Development of a Six Sigma Infrastructure for Cataract Surgery in Patients with Pseudoexfoliation Syndrome, Archives of Business Research, 2(2), 15-23.

Sahbaz, I., Taner, M.T., Sanisoglu, H., Kar, T., Kagan, G., Durmus, E., Tunca, M., Erbas, E., Armagan, I., Kagan, M.K. (2014d), Deployment of Six Sigma Methodology to Pars Plana Vitrectomy, International Journal of Statistics in Medical Research, 3(2), 94-102.

Sahbaz, I., Taner, M.T., Kagan, G., Sanisoglu, H., Erbas, E., Durmus, E., Tunca, M., Enginyurt, H. (2014e), Deployment of Six Sigma Methodology in Phacoemulsification Cataract Surgeries, International Review of Management and Marketing, 4(2), 123-131.

Sahbaz, I., Taner, M.T., Sahandar, U.T., Kagan, G., Erbas, E. (2014f), Elimination of Post-operative Complications in Penetrating Keratoplasty by Deploying Six Sigma, American Journal of Operations Research, 4(4), 189-196.

Sahin, I. (2008), Peritoneal Dialysis, Arik, N. and Dilek, M. (eds.) in Nephrology, Karakter Color Publications, 2nd edition, Istanbul, Turkey.

Stuart, S., Booth, T. C., Cash, C. J., Hameeduddin, A., Goode, J. A., Harvey, C., Malhotra, A. (2009), Complications of Continuous Ambulatory Peritoneal Dialysis, Radiographics, 29(2), 441-460.

Taner, M.T., Sezen, B., Antony, J. (2007), An Overview of Six Sigma Applications in Healthcare Industry, International Journal of Health Care Quality Assurance, 20(4), 
329-340.

Taner, M.T., Sezen, B. (2009), An Application of Six Sigma Methodology to Turnover Intentions in Healthcare, International Journal of Health Care Quality Assurance, 22(3), 252-265.

Taner, M.T. (2012), A Feasibility Study for Six Sigma Implementation in Turkish Textile SMEs, South East European Journal of Economics and Business, 7(1), 63-71.

Taner, M.T., Sezen, B., Atwat, K.M. (2012), Application of Six Sigma Methodology to a Diagnostic Imaging Process, International Journal of Health Care Quality Assurance, 25(4), 274-290.

Taner, M.T. (2013a), Critical Success Factors for Six Sigma Implementation in Large-Scale Turkish Construction Companies, International Review of Management and Marketing, 3(4), 212-225.

Taner, M.T. (2013b), Application of Six Sigma Methodology to a Cataract Surgery Unit, International Journal of Health Care Quality Assurance, 26(8), 768-785.

Taner, M.T., Kagan, G., Celik, S., Erbas, E., Kagan, M.K. (2013), Formation of Six Sigma Infrastructure for the Coronary Stenting Process, International Review of Management and Marketing, 3(4), 232-242.

Taner, M.T., Kagan, G., Sahbaz, I., Erbas, E., Kagan, S.B. (2014a), A Preliminary Study for Six Sigma Implementation in Laser in situ Keratomileusis (LASIK) Surgeries, International Review of Management and Marketing, 4(1), 24-33.

Taner, M.T., Sahbaz, I., Kagan, G., Atwat, K., Erbas, E. (2014b), Development of Six Sigma Infrastructure for Strabismus Surgeries, International Review of Management and Marketing, 4(1), 49-58. 